\title{
Health Search Behavior by The Scavenger in The Landfill Area
}

\author{
Hanny Hafiar ${ }^{1}$, Priyo Subekti ${ }^{2}$, Lukiati Komala ${ }^{3}$, Iriana Bakti ${ }^{4}$, Rosnandar Romli ${ }^{5}$ \\ Universitas Padjadjaran, Indonesia ${ }^{1-5}$ \\ \{hannyhafiar@unpad.ac.id $\left.{ }^{1}\right\}$
}

\begin{abstract}
The Scavenger profession, synonymous with garbage that is far from a healthy and clean impression. Therefore, scavengers face problems that are complex; however, as an individual, scavengers still trying to get healthy. Therefore, the purpose of this research was to determine the health-seeking behavior by scavengers. The method used is descriptive with data collection through questionnaires, interviews, and observation. As for the results include the behavior of health care, including eating nutritious food, drink plenty of water, enough rest, drinking supplements, hygiene, by sport, and sunbathing. While efforts are being made by a scavenger in the form of behavioral prevention of disease, namely: eating vegetables and fruit, lots of drinking, personal hygiene, reduce smoking, getting enough rest, keeping the environment clean, maintain the distance to the source of the disease, and drinking vitamin. As for the health seeking behavior is a mix of traditional medicine themselves, herbal medicine, go to the place of alternative medicine, buy drugs are sold freely in shops, ask and buy medicines in pharmacies, and go to the public health clinic (Puskesmas). Next, behavioral health recovery undertaken include: rest, away from the landfill, taking herbal medicine, taking medication, see your doctor and increase the consumption of foods and beverages that are nutritious
\end{abstract}

Keywords: Scavenger, Healthy, Medicine

\section{Introduction}

The health problem is a very complex problem, which is related to other problems beyond health itself. Similarly, solving the public health problem, not only in terms of health but must be seen in all aspects that affect these health problems. The health status is influenced by several factors, hereditary factors, health services, behavioral factors, and environmental factors. Humans do the activity of producing food, drinks, and other items to meet the needs of his life. Scavenger is an occupation where people who work in this job is always interacting with a dirty environment, which is not hygienic and full of health-threatening bacteria. It can be said that the working conditions of the scavengers of the Landfill are incompatible with the concept of health that generally known. The environment in which the final landfill is located is an area to accommodate waste from the carriage of a temporary landfill or directly from the source to the destination with the purpose to reduce the capacity or the garbage problem in society generally. 
Scavenger community is a community that is unique and different when compared with other communities such as panhandlers or buskers who roam the streets. At a glance, one may find scavengers roam around the residential population when scavengers are looking for second-hand goods, according to the scarcity of frequencies to meet with scavengers in the residential then people generally estimate that the number of scavengers is not too much. The longest average working hours of the scavengers in a day is between 8-9 hours. However, there are also about 1-3 scavengers who work for 14-15 hours. By looking at the length of their working time, then it can be known to be risk factors that can affect a person's health. With the long working time of the scavengers' in a landfill, then this indicates that the likelihood of the occurrence of disease risk is enormous because while they work, they interact with garbage that dirty and full of bacteria. Every day a scavenger came into the landfill which is the source of their livelihood. Landfill became a gathering place for the garbage produced by society and became a field of good fortune for the scavenger. Starting from second-hand goods even to the leftover food that they think can still be utilized. Regarding the food that has been discarded, according to the confession of the scavengers at the initial interview, is not a problem as long as it can still be eaten, and if the food was moldy, they can be cleaned. That is because so far they rarely or never experience stomach pain when eating leftover food from the landfill.

Also, around a pile of garbage, there are several tents set up by the scavenger to rest, to sit or to eat and drink, and also for napping to relieve fatigue after work. There are some scavengers who sell snacks such as fried foods, beverages, and its customers are also fellow scavengers. Ironically they are selling food in the middle of the pile of garbage that dirty, smelly and infested with flies, the question is whether they understand the concept of healthy? Or is the concept of the healthy that they understand, different from the prevailing concept of healthy during this time? Besides that, there are many scavengers who underestimate the functions of the personal protective equipment, which actually can afford a little care of their health from exposure to germs and disease organisms. Lack of sufficient understanding of the importance of personal protective equipment does not only happen in Indonesia as stated below: observations revealed that most waste handlers did not use PPGs consistently throughout a dayes work. Waste handlers such as community waste volunteers, scavengers and night soil collectors did not have functional PPGs available [1]. Each should understand the concepts of health because in turn can shape the attitudes and behaviors of individuals to live a healthy lifestyle. Based on the initial survey, the concept of ill, according to the scavenger is if they are unable to work. If they suffer from headaches, chills, or cough and cold but they still can work, it cannot be said to be ill. Though it is known that "health behaviors have important consequences for both the quality and length of life by influencing disease outcomes" [2]

The concept of healthy and sick have conceptual differences between one person and another, from one society to another, and will influence the differences in disease classification. From the difference, then any symptoms or pain by one community can be regarded as an illness, but on the other communities is not considered a disease or not perceived as ill. Healthy living is a situation in which human life is balanced physically, mentally, and socially. Knowledge about a healthy life should pay attention to the socialcultural background of the individual concerned. The experiences encountered during the period of the life of the individual in the process of internalization into knowledge accumulated in his memory and can be used at any time if he needs it. Knowledge of healthy and sick concept is based on the perception of scavengers is limited due to limited access to information. With his working conditions that require to work for almost a full day, access to 
information obtained by personal communication scavenger relies solely on word of mouth among fellow scavengers. The information component concerns the individual's trust and information about an object. Personal communication is one of the emotional power of belief and concept who are owned by the scavenger. Based on this phenomenon, the researchers wanted to know about health-seeking behavior and the use of health information by scavengers. How the information is obtained and what type of media used to distribute the information.

\section{Method}

The methods used in this research is the descriptive method using qualitative and quantitative data. Descriptive research aims to describe what is currently applicable. Inside are the attempt to describe, record, analyze and interpret the current conditions occur, or existThis research is intended as qualitative research that is intended as a type of research that generates descriptive data that can explain the circumstances of the informant, according to the nature of each setting. The reason why the researchers used the type of descriptive research is because the study was able to provide a thorough overview and clear picture of the situation of one social situation to another or for a specific time period to another, or to find patterns of the relationship between certain aspects with other aspects and can find hypotheses and theories. Data collected through the distribution of questionnaires, interviews, and observation. The selection of respondents is based on the purposive method with the criteria of the scavengers in the landfill who worked in various landfills in several cities in West Java, namely TPA Bantargebang Bekasi, TPA CikolotokPurwakarta, TPA CiangsanaSukabumi, TPA Patuguran Palabuhan ratu.

\section{Result and discussion}

The maintenance of public health is a shared responsibility. The government and society have a duty to improve the health of every citizen. Health care quality improvement can be done by way of maintenance, prevention, treatment and recovery, which is in line with this research results that state that: health efforts should be improved continuously to maintain and improve public health in the form of disease prevention, health promotion, disease treatment and health restoration [3]. Efforts to improve the quality of health can also be done by the government and related parties in the form of campaign or promotion of health. Health promotion includes efforts to motivate, encourage and raise awareness of the potential held by the public so that they are able to maintain and improve their health [4]. Covering every layer of society, including people who work as scavengers. The following will be elaborated results which include the responses given by the scavengers at several landfills in West Java, the first is the effort in the form of a scavenger Behavior in Healthcare, with the following results: 


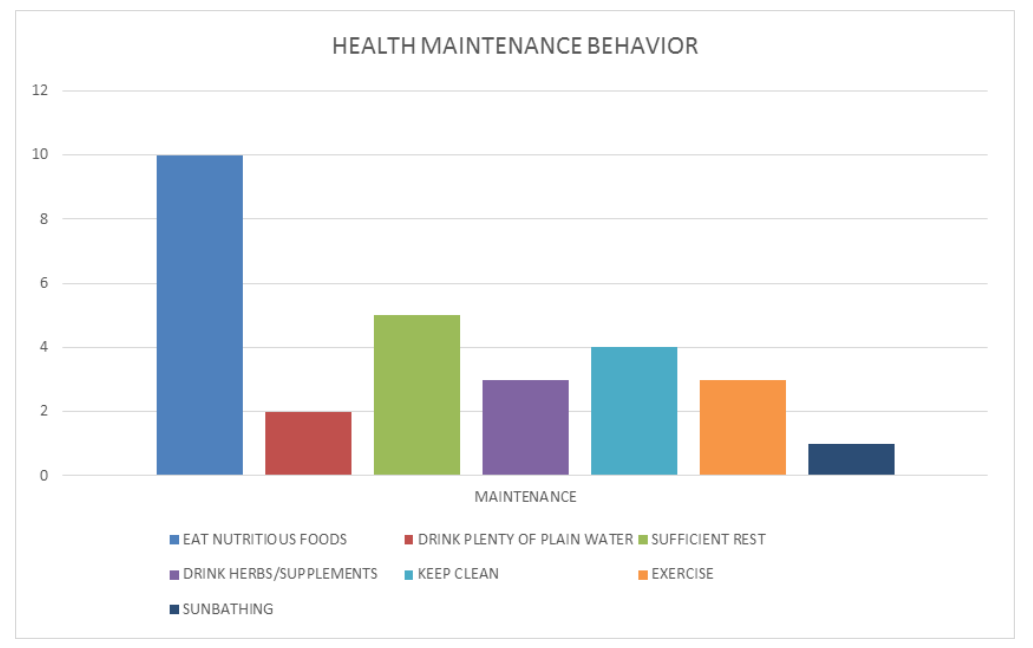

Figure 1 Scavenger's Health Maintenance Behavior

Based on the table then can be described that the health maintenance behaviors performed by scavenger most respondents answered a nourishing meal. The Ministry of Health pointed out that the state of good nutrition can improve the health of individuals and communities. Optimal nutrition is essential for normal growth and physical development and intelligence of babies, children, and every age group. Good nutrition makes a normal or healthy weight; the body is not susceptible to infectious diseases, labor productivity increased and protected from chronic disease and premature death. But if seen from the reality in the landfill, the scavengers eating unhealthy foods such as fried foods which sold in landfill areas, leftover food found in the trash, eating together in a landfill that is unhygienic and dirty. So it can be said the scavengers know by eating nutritious and healthy foods can support their health, but they cannot do much because the circumstances did not allow them to get healthy food. This is because healthy nutritious foods are expensive and they do not have enough money to buy it.

There is no single one of the food that has every nutrient the body needs to make sure growth and support health because it required a variety of foods to meet nutritional needs. Diverse as defined in this principle is to the diversity of types of food included the proportion of a balanced diet, in enough quantities, is not excessive and done regularly. Health Behavior of every individual is essentially a response to someone (organism) of stimulus-related illness and disease, health care systems, food, and environment [5]. Therefore, it is shown in the table above, some things do scavenger as health care behavior, including eating nutritious food, drink plenty of water, adequate rest, drinking herbal/supplements, hygiene, sports, and sunbathing to gain exposure sunlight at certain hours which are believed to have health benefits.

These things are done by a scavenger in connection with his knowledge to the health care effort. There are three factors that affect health, namely disease-causing factors, human factors, and environmental factors. The balance between these three factors required to obtain a desirable health condition[6]. Therefore, the knowledge about the causes of disease, maintaining the human immune system to prevent the infected diseases, and environmental hygiene, already owned scavengers though it may be superficial and limited knowledge because in practice it is difficult for scavengers to avoid the garbage which is one source of the 
disease. In addition to knowledge about health care, some scavengers are also known to plant some herbs in small pots around the house. This shows that most of the scavengers have had knowledge of the Toga (medicinal plants for family), according to the results of research that says that:Toga is expected to be used by the community for the first aid to health problems, could be one of the community's sources of income, making a beautiful yard, reducing the cost of family expenditure on drugs[7].Scavengers limited understanding of health can be improved through education so they have a basic knowledge of the disease, and how to keep themselves and the environment to stay healthy. It is stated in the following research results:Health behavior is essentially an individual's response to stimulate dealing with the disease, the health care system, food, and environment. The behavior of a person or the public heal this determined by knowledge. Factors that influence knowledge of someone or society is education. Education means the guidance given by one person to another person about something that they can understand [8].

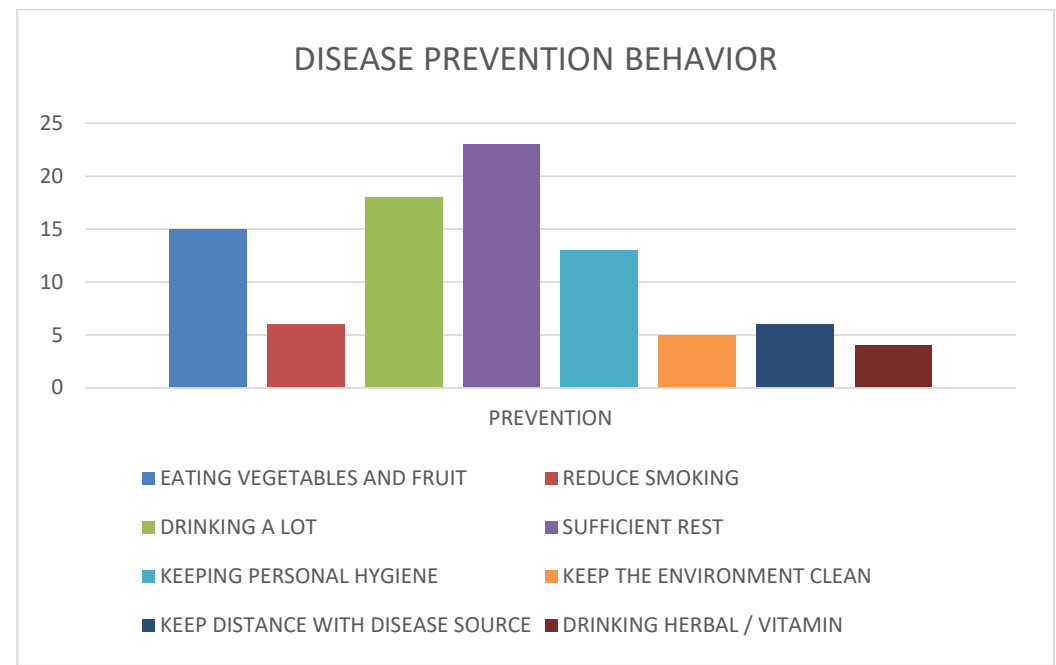

Figure 2 Disease Prevention Behavior by Scavengers

Based on the survey results revealed that there were attempts by scavengers in the form of the behavior of disease prevention, namely: eating fruits and vegetables, lots of drinking, personal hygiene, reduce smoking, getting enough rest, keeping the Environmentally clean, keep a distance from the source of the disease, and drinking herbal/vitamin. Some of the answers of the Interviewees are the things that belong to a clean and healthy living behavior. Basically, a scavenger had knowledge about the basics of healthy living behaviors, but they experience obstacles to implementing it. This is due to their work environment is a landfill. Their workplace is an environment that dirty and full of bacteria and each time they are always in contact with the garbage. This is the obstacle for scavengers to carry out a healthy lifestyle. The factors affect the health of both individuals, and the public health is the problem of the environment. This is because the environment where they live is a place where humans and illness agents can grow and develop together[9].

Clean and healthy behavior is an important factor in improving the quality of public health. But this healthy behavior should be guided by consciousness, because of health behavior committed in the consciousness of the family or family members can help themselves in the field of health and play an active role in the activities of public health [10]. Therefore, it is 
necessary for health campaigns by various parties to increase public awareness of the prevention of disease. This is consistent with the statement: messaging and communicator in the campaign can affect the knowledge, feelings, and behavior tendency toward self-health community [11]. One of the things that must be considered in the campaign is the audience. In principle, in traditional societies, contributing advice and decision makers in family health efforts is the mother. This is consistent with research that suggests that: women more took the decision to seek treatment alternative compared to men. Women are also many who seek treatment to pharmacies/drugstores when the symptoms of the disease appear [12].

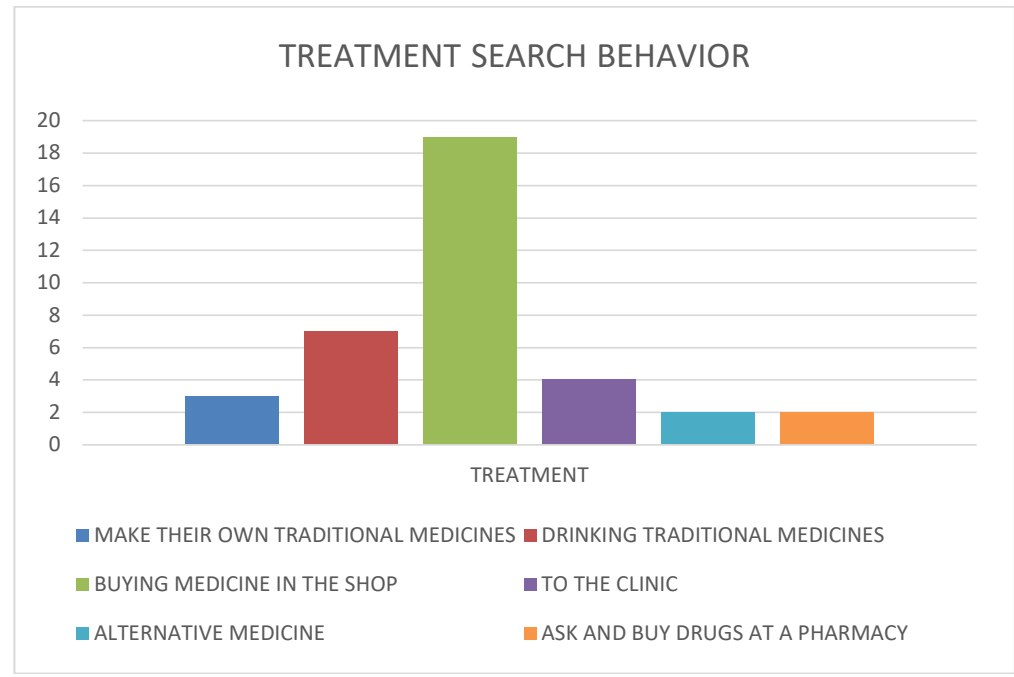

Figure 3 Treatment Search Behavior by Scavengers

In principle, the concept of a person's response to pain is not the same. People who get sick, but didn't feel the pain is certainly not making any attempt against his illness. Otherwise, people who get sick but feeling the pain certainly will attempt to seek treatment [12]. Therefore, health-seeking behavior performed by the scavengers when they felt their pain conditions among which are: makes their own traditional medicine, drank herbal medicine, go to alternative medicine, buying drugs that are sold in stalls, ask and buy drugs at a pharmacy, and go to the clinic. Scavenger habit of seeking alternative treatments and buying nonprescription medicine from the store is inseparable from economic factors and knowledge of women who dominate the household. This is in accordance with the conclusions of the research data reveals that: there is the influence of health education on behaviors of clean living and healthy in order to knowledge household housewife[3]. As for economic reasons, referring to the statement: By looking at the current economic situation, it seems that society must react appropriately, one of which is the pattern of economic life or the life-saving. The current simplest strategy is to make savings that can be made in all areas, including in the health area [13].

Maternal knowledge about alternative medicine is inseparable from the role of the media because the ad impressions that promote drugs and health services increasingly rampant in television, both local and networked television. So the housewife who watched a lot of alternative medicine tend to want to try alternative medicine or traditional medicine to obtain relief. Therefore, health information dissemination in the corridors of alternative medicine 
needs the supervision and assistance of the government. Two of the three basic wisdom of The Traditional Medicine Program adopted by The World Health Assembly and The Regional Committees describe their attention to the fact that, (1) general world population depends on traditional medicine for their first health care; (2) the workforce represented by traditional healers are a potential source of health care delivery [14].

The reason why the community did its own treatment because the community or society believes in the treatment by themselves, and it was felt that based on their own past treatment experience efforts already can bring healing. As a result, the search for treatments other than by itself is not required. The example of healing treatment by themselves are scraping, massage, make herbal medicine, and buying OTC or nonprescription medicine in a pharmacy or drug stalls [12]. Other research results also offer a similar view by stating namely: A larger proportion of Indonesians seek alternative healthcare beyond westernized medical treatment. Some people use a naturalistic approach to cure their ailments, such as consuming herbal medicine, getting massages or acupuncture [15]. Another case with the research carried out by Taufik on scavenger health conditions are The scavenger health condition. A fairly strong influence mainly from the air containing the toxic methane gas which will then affect the respiratory tract, besides the other indicators is housing not well-ordered [16].

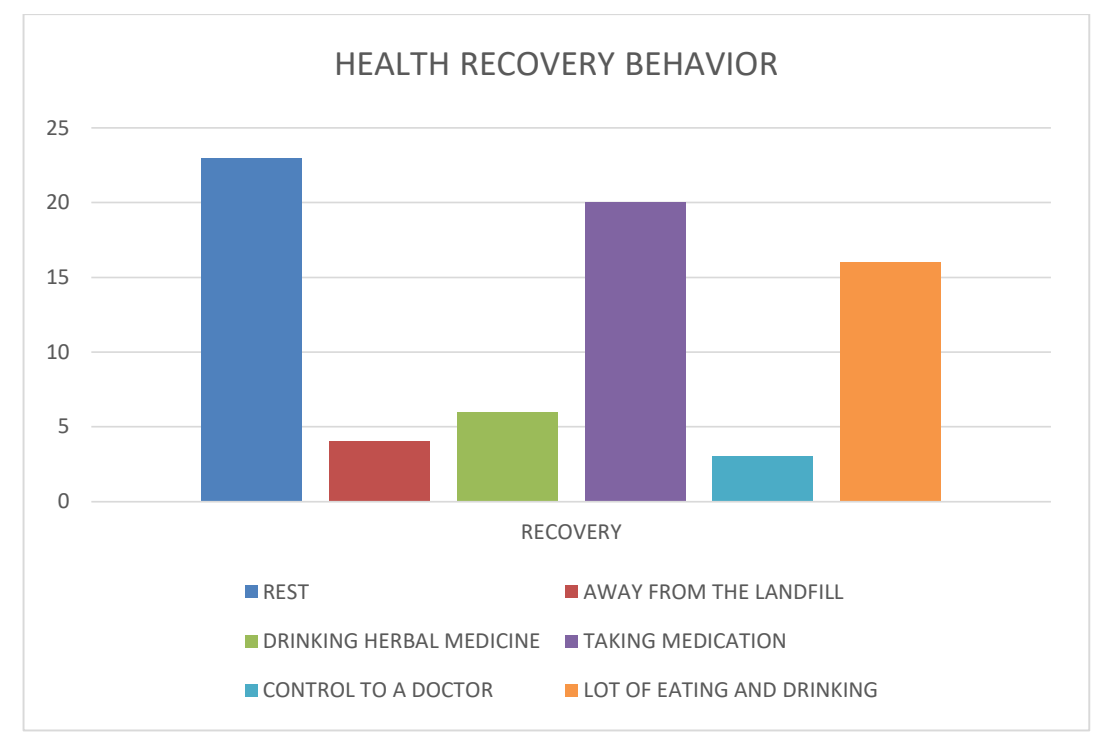

Figure 4 Scavenger's Health Recovery Behavioral

The findings, based on interviews and observations of a number of scavengers known that health recovery, behavioral undertaken include: rest, away from the landfill, taking herbal medicine, taking medicine, control to a doctor and increase the consumption of nutritious foods and beverages. Based on these data, then it was found again that drinking herbal medicine is one part of alternative medicine, as also expressed by scavengers because drinking herbal medicine is one part of the habit that already is widespread in Indonesia. This is in accordance with the statement: Many communities who go to alternative medicine because society is still simple, healthy and sick problems are more cultural than physical disorders. 
Identical to the treatment seeking was more oriented to the social and cultural rather than things that are considered being foreign [12].

Indeed, there is not a problem when scavenger chooses alternative medicine as long as the information about the alternative treatment is the correct information and can be accountable. In this case, health workers usually have difficulty in communicating with the socialization process to align the public confidence about alternative medicine. As a matter of fact, there have been attempts from certain parties to give health information to the community, but as shown by this research that: "When asked to rate sources of communication channel to obtain health information, we found that the majority of the respondents preferred traditional mass media such as TV and radio"[17]. This means that TV and Radio are still the main media chosen by this community to seek information, including health information. Even though for some cases of health experienced by a scavenger, should be done with socialization, considering the limitations of these community groups in accessing media information.

Nevertheless, socialization activities are still experiencing some constraints. The obstacles in the socialization process include the difficulty of communication, different behavior patterns, and due to changes in society[18]. So often, the patient then switched to medical/medicine-based treatment in severe health conditions. Based on other research found that: Scavenger communication experience in maintaining their own health and the environment is different. Depending on the background or experience of the individual. Awareness to maintain their own health and the environment is also influenced by the experience of each scavenger. Of course, scavengers who had suffered from a disease in the past will have a bigger awareness to maintain their own health. This is in contrast to the scavengers with no disease history, they will be less concerned with their health [19]. In an effort to increase the awareness of scavenger about their health, it would require intensive health communication. Healthy communication is a study which emphasizes the role of communication theory that can be used in research and practice related to health promotion and health care[20]. As for how the dissemination of health information to the scavengers community can be done is by gethok tular. Gethok tular is a way of communication that is done from mouth to mouth. This strategy is a highly effective strategy to reach other communities [21].

\section{Conclusion}

The Some things can be concluded based on the results and discussion includes health maintenance behaviors, among them: eat nutritious foods, drink plenty of water, enough rest, taking herbs/supplements, hygiene, exercise, sunbathing to obtain exposure to sunlight at certain hours which are believed to have health benefits. While efforts scavengers in the form of disease prevention behaviors, namely: eating fruits and vegetables, drinking, personal hygiene, reduce smoking, getting enough rest, keeping the environment clean, maintain the distance to the source of the disease, and drinking herbal/vitamin.

As for the health seeking, behavior performed by the scavengers when they felt they are in pain conditions include: mixing traditional medicine by themselves, drink herbal medicine, go to alternative medicine, buying drugs that are sold in stalls, ask and buy drugs at a pharmacy, and went to the clinic. Next, health recovery behavior undertaken by rest, away from the landfill, taking herbal medicine, taking medication, see the doctor and increase the consumption of nutritious foods and beverages.

Furthermore, the recommendations can be suggested based on the research results include: the intensification of the activities of health communication by the parties to the community of 
scavengers, using communication gethok tular in minimizing communication difficulties, and work together with the parties that have an impact on scavengers community members in informal structures, to convey simple health messages. Furthermore, the recommendations can be suggested based on the research results include: the intensification of the activities of health communication by the parties to the community of scavengers, using communication gethok tular in minimizing communication difficulties, and work together with the parties that have an impact on scavengers community members in informal structures, to convey simple health messages

\section{References}

[1] J. Kretchy et al., "Exposure , protection and self-reported health problems among solid waste handlers in a Coastal Peri-urban community in Ghana," Int. Sch. Journals, vol. 4, no. 2, pp. 121-128, 2015.

[2] M. Conner, "Health Behaviors," Int. Encycl. Soc. Behav. Sci., 2002.

[3] R. Artanti, "Pengaruh Pendidikan Kesehatan Tentang Perilaku Hidup Bersih Dan Sehat Tatanan Rumah Tangga Terhadap Pengetahuan Ibu Rumah Tangga Di Desa Surodadi Kecamatan Candimulyo Tahun 2012.," J. Komun. Kesehat., vol. 7, no. 2, pp. $1-9,2013$.

[4] U. Wahyudin and H. S. Arifin, "Sosialisasi Sanitasi Diri Dan Lingkungan Di Pesantren Salafi Melalui Pos Kesehatan Pesantren (Poskestren) Dalam Membentuk Sikap Santri Terhadap Sanitasi,” J. Kaji. Komun., vol. 3, no. 2, pp. 148-153, 2015.

[5] E. U. Dewi, "Pengaruh Pendidikan kesehatan Terhadap Perilaku Hidup Bersih Dan Sehat Pada Pemulung di TPA Wonokromo Surabaya," J. Keperawatan, vol. 4, no. 1, 2015.

[6] Rochgiyanti, T. Nurdiyana, S. Ruswinarsih, Y. Apriati, and S. Mattiro, "Perilaku Pemulung dalam memahami pola hidup sehat di TPA Basirih Banjarmasin,” 2010.

[7] I. Bakti, E. A. S. Dewi, R. Romli, and H. R. Budiana, "Analisis Faktor Personal Pada Sumber Komunikasi Dalam Pengelolaan Tanaman Obat Keluarga Di Jawa Barat," J. Kaji. Komun., vol. 3, no. 2, pp. 133-139, 2015.

[8] Indasah, N. Z. Maula, and P. Dewi K, "Relationship of Behaviour in the Use of Personal Protective Equipment ( APD ), Eating a Healthy and Balanced , and Personal Higiene to Health Status of Skin on Scavengers in Tpa Kediri," J. Appl. Environ. Biol. Sci., vol. 6, no. 2, pp. 1-5, 2016.

[9] R. I. Ottay, "Hubungan antara perilaku pemulung dengan kejadian penyakit cacingan di tempat pembuangan akhir sampah Sumompo Kota Manado.," Biomedik, vol. 2, no. 1, pp. 38-43, 2010.

[10] A. Purwati, A. Maliya, and F. Nur Rosyid, "Gambaran perilaku hidup bersih dan sehat di masyarakat sekitar TPA Putri Cempo Surakarta," Universitas Muhammadiyah Surakarta, 2013.

[11] G. Citrasiwi, H. Hafiar, and D. F. Sjoraida, "Pembentukan Sikap Masyarakat Terhadap Kesehatan Diri Melalui Kampanye 10 Perilaku Hidup Bersih Dan Sehat," J. Visi Komun., vol. 14, no. 2, pp. 136-145, 2017.

[12] R. Kristiono and Y. Wardani, "Faktor-Faktor Yang Berhubungan Dengan Pola Pencarian Pengobatan Ke Pelayanan Kesehatan Alternatif Pasien Suspek Tuberculosis Di Komunitas," J. Kesmas, vol. 7, no. 2, pp. 105-112, 2013.

[13] C. P. Dini and P. Lestari, "Literasi informasi tentang kemasan produk obat bebas," J. Komun. ASPIKOM, vol. 2, no. 5, pp. 357-373, 2015. 
[14] N. Kasniyah, "Fenomena Budaya Dalam Penyembuhan Penyakit Secara Tradisional : Pijat Refleksi dan Transfer Penyakit dengan Media Binatang," J. Masy. Kebud. dan Polit., vol. 22, no. 4, pp. 333-342, 1993.

[15] D. Mulyana and Sulaeman, "People with Lobster - Claw Syndrome: A Study of Oligodactyly Sufferers and their Communication Experiences in the Village of Ulutaue, South Sulawesi, Indonesia,” Mediterr. J. Soc. Sci., vol. 7, no. 1, pp. 136-144, 2016.

[16] I. Taufik, "Persepsi masyarakat terhadap pemulung di pemukiman tpa kelurahan bukit pinang kecamatan samarinda ulu,” J. Sosiol., vol. 1, no. 4, pp. 85-95, 2013.

[17] R. Mohd-Nor, T. E. Chapun, and C. R. J. Wah, "Malaysian Rural Community As Consumer of Health Information and Their Use of ICT," J. Komun. Malaysian J. Commun., vol. 29, no. 1, pp. 1-27, 2013.

[18] K. Komariah and P. Subekti, "Penggunaan Media Massa Sebagai Agen Sosialisasi Dinas Kesadaran Masyarakat Akan Pentingnya Imunisasi,” J. Profesi Humas, vol. 1, no. 1, pp. 12-21, 2016.

[19] S. Nurtyasrini and H. Hafiar, "Pengalaman Komunikasi Pemulung Tentang Pemeliharaan Kesehatan Diri Dan Lingkungan Di TPA Bantar Gebang," J. Kaji. Komun., vol. 4, no. 2, pp. 219-228, 2016.

[20] K. Komariah, S. Perbawasari, A. R. Nugraha, and H. R. Budiana, "Pola Komunikasi Kesehatan dalam pelayanan dan pemberian Informasi mengenai Penyakit TBC pada Puskesmas di Kabupaten Bogor,” J. Kaji. Komun., vol. 1, no. 2, pp. 173-185, 2013.

[21] R. Darmastuti, A. Bajari, H. S. Martodirdjo, and E. Maryani, "Gethok Tular, Pola Komunikasi Gerakan Sosial Berbasis Kearifan Lokal Masyarakat Samin Di Sukolilo," J. ASPIKOM, vol. 3, no. 1, pp. 104-118, 2016. 